E-ISSN: 2808-5361 http://e-journal.fkmumj.ac.id/
Proceeding The First

Muhammadiyah

Internasional-Public Health

and Medicine Conference

\title{
The Benefits of Consuming Sardines to Prevent Hypertension and Type 2 Diabetes Mellitus for Senior Citizens
}

\author{
${ }^{1}$ Vallensia Nurdiana Febriyanti \\ ${ }^{1}$ Master of Public Health, Muhammadiyah University of Jakarta \\ Jl. K.H. Ahmad Dahlan, Cireundeu, Ciputat, Jakarta Selatan. 15419 \\ ${ }^{2}$ Prodia Senior Health Centre \\ Jl. Metro Pondok Indah TB-31, Kebayoran Lama, Jakarta Selatan \\ 3 Yadika Hospital Kebayoran Lama \\ J1. Ciputat Raya No.5, Jakarta Selatan, 12240 \\ E-mail: dr.vallensia@gmail.com
}

\begin{abstract}
Along with the increasing number of senior citizens in Indonesia, the number of cases of noncommunicable diseases (NCDs), especially hypertension and diabetes mellitus experience escalation too, which certainly will have a direct impact on human resource productivity, social and economic development. In addition, hypertension and type 2 diabetes mellitus are the causes of the highest mortality rates in Indonesia. This article aims to encourage the public especially the senior citizens to prevent hypertension and type 2 diabetes mellitus by consuming fish containing high omega 3, EPA, and DHA, such as sardines at least twice a week or the equivalent of 200-400 grams a week. In terms of the methods, a literature study approach was employed in elaborating the research topic. The findings of this study demonstrate that sardines contain anti-inflammatory, antioxidant roles, boost the membrane fluidity, boost the number of insulin receptors and insulin action, and also contain hypotensive and hypoglycemic effects. In this manner, sardines are highly proven to be able to effectively prevent type 2 diabetes mellitus, prevent hypertension, and lower blood pressure, especially for senior citizens.
\end{abstract}

Keywords: Hypertension, Diabetes, Sardines, Prevention, NCDs 


\section{INTRODUCTION}

The senior citizen population in Indonesia is gradually increasing every year. This is evidenced by data which indicates that the growth in the number of senior citizens in 2010 as many as 18 million people (7.56\%) to 25.9 million people (9.7\%) in 2019. It is estimated that this number will continue to grow, 27.1 million people (9.99\%) in 2020, 42.0 million people $(13.82 \%)$ in 2030, and 48.2 million people $(15.77 \%)$ in 2035. Currently, Indonesia is moving towards an aging population structure, a situation where an increase in life expectancy is followed by an increase in the number of senior citizens (Riskesdas, 2018).

Along with the growing number of senior citizens in Indonesia, the incidence of noncommunicable diseases (NCDs) will certainly increase as well. According to data from the Indonesian Ministry of Health, the rate of NCDs in Indonesia has reached 69.91\% in 2019. Based on the Basic Health Research data from the Ministry of Health in 2018, non-communicable diseases that mostly affect the senior citizens in Indonesia include; hypertension, diabetes mellitus, heart disease, stroke, dental problems, joint disease, and oral problems (Riskesdas,2018).

Among several types of non-communicable diseases, only the prevalence of hypertension continues to grow unquestionably in Indonesia. This is in line with data obtained from the Indonesian Ministry of Health in 2018 which stated that significant growth was found in 2013 which initially was only $25.8 \%$ growing significantly to $34.11 \%$ in 2018 . The number of hypertension cases is also clinically proven to have increased as humans get older. Based on the data obtained from the Indonesian Ministry of Health, in 2018 patients with hypertension at the age of 18-24 years were $13.2 \%$, aged $25-34$ years were $20.1 \%$, aged $35-44$ years were $31.6 \%$, aged $45-54$ years by $45.3 \%$, age 55-64 years by $55.2 \%$, age $65-74$ years by $63.2 \%$, age 75 years by $69.5 \%$. While based on a survey conducted by all hypertensive patients, it was found that $32.27 \%$ of hypertensive patients did not regularly take medication and $13.33 \%$ did not take medication at all. Then from the data, it was found that $59.8 \%$ of hypertensive patients did not want to take any medication regularly because they felt they were already in good condition. (Kemenkes RI, 2018).

In fact that in addition to the prevalence of hypertension which has increased dramatically, in fact, the prevalence of people with diabetes mellitus has also increased, although not as much as people with hypertension. Based on the findings of a study conducted by the 2018 Ministry of Health Basic Health Research, the prevalence of diabetes mellitus also increases as humans get older, the highest DM sufferers are between 55-64 years old represented by 6.3\%, and between 65-74 years old represented by 6.03\%. (Kementrian Kesehatan RI, 2018). 
Based on a report presented by WHO, in 2016, diabetes caused 1.5 million deaths in 2012, and 2.2 million deaths due to complications from increased blood levels that exceed the maximum limit, such as cardiovascular disease and others. As many as $43 \%$ of the total 3.7 million deaths occurred before the age of 70 (WHO, 2018).

Table 1. Diabetes Mellitus Diagnosis according to Perkeni, 2015

Diabetes Mellitus Diagnosis according to Perkeni (2015)

a. Examination of fasting glucose levels $\geq 126 \mathrm{mg} / \mathrm{dl}$

b. Two-hour postprandial blood sugar (GD2PP) or oral glucose tolerance test (OGTT) $200 \mathrm{mg} / \mathrm{dl}$

c. Examination of plasma glucose as $200 \mathrm{mg} / \mathrm{dl}$ with classic complaints

d. Examination of HbA1c 6.5\% (NGSP)

Table 2. Prediabetes Criteria according to Perkeni, 2015

\section{Prediabetes Criteria According to Perkeni}

a. Examination of fasting glucose levels $100-125 \mathrm{mg} / \mathrm{dl}$

b. Two-hour postprandial blood sugar (GD2PP) or oral glucose tolerance test (OGTT) 140-199 mg/dl

c. Examination of $\mathrm{HbA} 1 \mathrm{c} 5.7 \%-6.4 \%$ (NGSP)

Based on data presented by the 2018 Ministry of Health Basic Health Research, the prevalence of non-communicable diseases that cause the highest death in Indonesia is hypertension with a percentage of $34.1 \%$, stroke $10.9 \%$, diabetes mellitus $8.5 \%$, kidney failure $3.8 \%$, cancer $1.8 \%$, and heart disease $1.5 \%$. (Riskesdas, 2018).

The higher incidence of non-communicable diseases (NCDs) in Indonesia from year to year, especially hypertension and diabetes mellitus will certainly have an impact on the productivity of human resources, social, and economic development. This encourages the Ministry of Health to be more aggressive with the Healthy Living Community Movement (GERMAS) program, to build awareness of the Indonesian people about the importance of healthy living, which in turn will improve the quality of life of all Indonesian people. (Kemenkes RI, 2019).

Thus, this article aims to encourage the Indonesian people to consume balanced nutritious food by adding fish as a side dish which is rich in omega 3, EPA, and DHA, such as sardines at least twice a week or equivalent to 200-400 grams a week, to reduce the incidence rate of hypertension and type 2 diabetes mellitus in Indonesia.

\section{DISCUSSION}

Omega 3 fatty acids belong to long-chain polyunsaturated fatty acids (FA). Omega 3 fatty acids that are good for health include sea-derived Eicosapentaenoic acid (EPA) and Docosahexaenoic acid (DHA). The main sources of omega 3, EPA, and DHA are fish oil and various seafood (Jubbin, 2013). 
Marine water fish such as sardines, salmon, mackerel, tuna, and herring have a high content of omega 3 but with relatively low levels of saturated fatty acids. Among these fish, sardines is the easiest to find in Indonesia. Assuredly the price of the fish is much cheaper when compared to other types of fish. According to research data, freshwater fish tend to contain less omega 3 when compared to marine water fish. It is believed that the omega 3 content found in fish is triggered by how the fish survives in a particular habitat (NIH,2019) (Calder, 2016). However, fish raised inadequate farms can also have high levels of omega 3 due to the type of feed provided is high quality. Besides being rich in omega 3, Sardines, salmon, mackerel, tuna, and herring are also rich in EPA and DHA. However, the condition of the fish, both fresh and canned, also affects the nutritional content of the fish. Based on the findings of a study, it was revealed that the DHA levels contained in canned salmon were reduced by $60 \%$ to 0.63 grams when compared to fresh salmon (NIH, 2019). As a result, fresh fish is certainly a better choice than canned fish. Therefore eating fresh sardines is the best way to get all of its nutritional content. However, if fresh sardines are difficult to obtain, they can be substituted by consuming fish oil. (Byelashov, et al, 2015). Eating fish regularly is highly recommended so that the daily needs of omega 3, EPA, and DHA are fulfilled. Although the highest levels of DHA are only found in Salmon and Herring, Sardines also contain high levels of omega 3, EPA, and DHA. According to the EFSA, in 2012 the normal limit for Omega 3 consumption ranges from 40-200 mg per day. (EFSA, 2012)

Diaz et al, 2021 stated that omega 3 fatty acids (FA), EPA, and DHA have an antiinflammatory role that can increase membrane fluidity, the number of insulin receptors, and insulin action. This is based on a study conducted by Ruzzin J et al, 2010 and Calder et al, 2017. According to Diaz et al, 2021, the group of subjects with type 2 diabetes mellitus prevention through creating diet intervention by consuming sardines demonstrated increased levels of taurine, EPA, DHA, total omega-3 nutrients, omega-3 fatty acids (FA), minerals (such as calcium, iodine, zinc, phosphorus, and fluoride) and vitamins (such as B12 and D). In addition, levels of other antioxidants such as lycopene and total tocopherol also increased. This certainly supports the fact that sardines are very rich in nutrients, amino acids, vitamins, and minerals. In addition, Sardines also contain olive oil. On the other hand, increasing levels of vitamin D, calcium, and zinc in respondents can have a good effect on the prevention of type 2 diabetes mellitus, as evidenced in previous studies by Eshak ES et al,2018 and Pittas AG et al, 2017. (Diaz, et al, 2021)

Sardines are fish that are also rich in amino acids. Based on the findings of a study conducted by Balfego et al, 2016 the amino acids present in Sardines include taurine with a concentration of $147 \mathrm{mg} / 100 \mathrm{~g}$ per serving. According to Schaffer et al,2010 the taurine content in 
Sardines is thought to have hypoglycemic, antioxidant, and anti-inflammatory effects. Thus Sardines are clinically proven in the prevention of type 2 diabetes mellitus and hypertension. Besides being rich in nutrients, sardines are also one of the fish with the lowest contaminant content, easy to obtain, and affordable for most consumers. Thus, Sardines are proposed as a good candidate for dietary nutrition intervention to prevent type 2 diabetes mellitus and hypertension. Eating sardines twice a week for one year has been shown to reduce the risk of type 2 diabetes mellitus both in the prediabetes and senior citizens groups. According to a study conducted by Diaz et al., 2021, 152 subjects with fasting glucose between 100-124 mg/dL aged 65 years were recruited from three primary care centers in Barcelona and randomly distributed into two intervention groups: the control group (CG) and sardine group (SG). Both groups received the same diabetes mellitus preventive nutrition treatment for a year but only SG had to add $200 \mathrm{~g}$ of sardines per week. All variables were collected and recorded both before starting the treatment and after the treatment. Surprisingly it was found an increase in HDL-cholesterol and adiponectin levels as well as a decrease in triglyceride levels $(\mathrm{p}<0.05)$ and blood pressure $(<\quad 0.05)$, SG demonstrated a lower HOMA-IR $(\mathrm{p}$ $=0.032$ ). Nutrient intake of omega 3, EPA and DHA, vitamin D, fluorine, and taurine was higher in $\mathrm{SG}(\mathrm{p}<0.05)$. These results were in line with the increase in circulating levels of taurine, omega 3 fatty acids (FA), and bile acid metabolites $(\mathrm{p}<0.05)$. Changes in erythrocyte membrane FA were detected only in SG with a decrease in 5 omegala 6 FA $(p<0.001)$ and an increase in 3 omega 3 FA types $(\mathrm{p}<0.001$ ). Thus, it can be concluded that the prevention diet treatment for type 2 diabetes mellitus for a year with Sardines supplementation has a greater effect on preventing type 2 diabetes mellitus and hypertension (Diaz et al,2021). Nevertheless is different from the findings of a previous study conducted by Mariona et al, 2016, which stated that the nutritional intervention of a sardine diet with $100 \mathrm{~g}$ of sardines 5 days a week for 6 months compared to a standard type 2 diabetes diet in people with diabetes mellitus type 2 did not find a significant difference in glycemic control between CG and SG groups. At the end of the treatment, both groups lowered plasma insulin (SG: $35.3 \%, \mathrm{P}=0.01, \mathrm{CG}: 22.6 \%, \mathrm{P}=0.02$ ) and homeostasis assessment model - insulin resistance (HOMA-IR) (SG: $39.2 \%, \mathrm{P}=0.007, \mathrm{CG}: 21.8 \%, \mathrm{P}=0.04$ ) in the last 6 months. It appears to have a neutral effect on glycemic control in patients, although this nutritional intervention may have a beneficial effect on cardiovascular risk. With this, it may be concluded that the sardine supplementation diet treatment has a better effect on preventing type 2 diabetes mellitus in the prediabetes group, however has no significant effect for people with diabetes mellitus. Therefore further research is highly required (Mariona, et al, 2016). 
Type 2 diabetes mellitus mostly affects people aged $>40$ years, and rarely affects adolescents and children (Purba, 2009). This is by Alfiyah's research, 2010 which stated that there is a significant relationship between age and the incidence of diabetes mellitus. Respondents aged 40 years have a greater risk of suffering from type 2 diabetes mellitus than those aged $<40$ years (Alfiyah, 2010). The findings of this study are in line with the research conducted by Wicaksono, 2011 which revealed a significant relationship between age and the incidence of type 2 diabetes mellitus. The findings of this study indicate that people aged 45 years have 9.3 times the risk of suffering from type 2 diabetes mellitus which is greater when compared to people aged <45 years (Wicaksono, 2011). The American Diabetes Association also states that the risk of type 2 diabetes increases with age. (ADA, 2011)

Age is one of the risk factors for type 2 diabetes mellitus, the older the age, the prevalence of type 2 diabetes mellitus increases. This is due to the decreased function of the insulin-producing pancreatic beta cells and the reduced number of insulin receptors on the cell surface triggered by aging. Therefore the sensitivity to insulin decreases. Under normal circumstances, the pancreas will produce insulin, and then insulin will bring blood glucose into the cells. However, when the function of pancreatic beta cells decreases, the insulin sensitivity decreases, so that glucose accumulates in the blood and cannot enter the cells causing the cells to become deficient. (Sudoyo et al, 2006)

Impaired glucose tolerance in type 2 diabetes mellitus is also influenced by the following organs, including; muscle, liver, adipose tissue (lipolysis), gastrointestinal (incretin deficiency), pancreatic alpha cells (hyperglucagonemia), kidney (increased glucose absorption), and brain (insulin resistance) (Perkeni,2015)

In addition, type 2 diabetes mellitus is strongly influenced by genetic factors. Based on research findings, if one of the parents suffers from type 2 diabetes, then the child has a $15 \%$ risk of suffering from type 2 Diabetes Mellitus. If the child whose mother has type 2 Diabetes Mellitus, he or has a 10-30\% greater risk than those whose father has type 2 Diabetes Mellitus, and the risk is greater than $75 \%$ whenever both parents suffer from type 2 diabetes. (Alfiyah, 2010) (Valdez, et al, 2007)

Blood glucose levels that do not meet the normal criteria and do not meet the diagnostic criteria for DM are categorized as prediabetes. The criteria for prediabetes according to Perkeni (2015), known as the PERKENI Recommendation, currently follow the recommendations of the American Diabetes Association (ADA), namely the condition when fasting blood glucose is disturbed (GDPT), impaired glucose tolerance (TGT), and the results of the examination of the 
Prediabetes Diagnosis Criteria. Prediabetes is a term used to describe a condition when glucose levels exceed normal but are not sufficient to make a diagnosis of diabetes mellitus. (ADA,2015) (Perkeni, 2015)

Prediabetes is a reversible condition. This sparked the development of many therapies or programs to prevent diabetes. One of them is a weight loss program with nutritional intervention, with a calorie restriction which is believed that with weight loss, the risk of type 2 diabetes mellitus will also decrease. However, the program is not recommended for the senior citizen since several epidemiological studies have demonstrated that decreased weight gain in the senior citizen leads to increased mortality. (Hamman, et al,2006)

Dietary interventions that are more suitable for senior citizens are dietary changes. This is by the research findings of Diaz et al, 2019 states that senior citizens are recommended to consume foods rich in Omega 3, EPA, and DHA, one example of which is Sardines. (Diaz et al., 2019) This statement is also supported by the research of Diaz et al., 2021 which states that the nutritional diet intervention for the prevention of type 2 diabetes mellitus with additional consumption of $200 \mathrm{~g}$ of Sardines $(\mathrm{n}=75)$ per week for 12 months for senior citizens respondents have significantly reduced the risk of the prediabetes group becoming diabetes $(\mathrm{p}=0.035)$. These findings were in stark contrast when compared to the diet group without any additional sardines consumption $(\mathrm{n}=$ 77). This finding is based on the assessment of the FINDRISC questionnaire, decreased HbA1C levels, and blood glucose levels in respondents. (Diaz et al, 2021) These findings certainly are in line with results demonstrated by other previous nutritional intervention studies. (Glushakova, et al, 2008)

The respondent's adherence to the diet of Sardines for 12 months, seen from the MEFA composition, indicated an increase in the levels of EPA and DHA in the respondents. It is considered a dietary biomarker with good adherence to nutritional interventions. On the other hand, increased levels of FA omega 3 in respondents may show a preventive effect of type 2 diabetes mellitus through increasing cell membrane fluidity which is an important mediator linking FA intake and metabolism with the risk of type 2 diabetes mellitus (Diaz et al, 2021) (Kroger et al., 2015) The decrease in the five subtypes of FA omega 6 in respondents with the intervention of consuming Sardine consumption in which the subtype FA Omega 6 can increase the risk of type 2 diabetes mellitus indicates a good preventive effect on type 2 diabetes mellitus (Diaz et al, 2021) (Alhazmi A, 2014) This is supported by scientific literature, Sertoglu et al., 2014 where levels of the FA omega 6 subtype increased in type 2 diabetes mellitus patients. The FA omega 6 subtype is believed to be a pro-inflammatory, predictor of worsening hyperglycemia and decrease insulin sensitivity and is 
closely related to the condition of type 2 diabetes mellitus with severe complications (Diaz et al, 2021) (Sertoglu et al, 2014) (Koehrer et al,2014)

According to WHO, hypertension is a condition in which systolic blood pressure $140 \mathrm{~mm} \mathrm{Hg}$ and/or diastolic blood pressure $90 \mathrm{~mm} \mathrm{Hg}$. Normal adult blood pressure is systolic blood pressure $120 \mathrm{~mm} \mathrm{Hg}$ and diastolic blood pressure $80 \mathrm{~mm} \mathrm{Hg}$. Normal systolic and diastolic blood pressure is very important to maintain the function of vital organs such as the heart, brain, kidneys, and other organs of the body. (WHO, 2013)

The risk factors for hypertension consist of modifiable risk factors and non-modifiable risk factors. The modifiable risk factors include obesity, excessive salt consumption, lack of physical activity, smoking, alcohol consumption, and stress. While the risk factors that cannot be modified include heredity, gender, age, and race. In general, hypertension occurs with age, but such a condition is not regarded as healthy aging. Hypertension in the senior citizen is triggered by decreased aortic wall elasticity, thickening of heart valves, atherosclerosis, decreased ability of the heart to pump blood so that the ability to contract and its volume decreases as well as increased peripheral vascular resistance. (Tambayong, 2001) (Padila, 2013)

The findings of a study conducted by Paige et al., 2014 indicated that EPA and DHA were equally effective in lowering blood pressure in the hypertensive population who did not take antihypertensive drugs. This also sanction the 2006 study of Dickinson et al. which stated that in some cases consumption of EPA and DHA was more effective in reducing high blood pressure compared to other lifestyle interventions, such as increasing physical activity, limiting alcohol consumption, and sodium. (Paige et al, 2014) (Dickinson et al,2006) The findings of this study also bolster the findings of Campbell et al, as well as previous meta-analyses Morris MC, 1993 and Geleijnse JM,2002. (Paige et al, 2014) (Campbell,2013)

EPA and DHA are believed to reduce systemic vascular resistance through changes in endothelial function so that they can lower blood pressure. Decreased systemic vascular resistance and blood pressure can also reduce the risk of coronary plaque rupture, stroke, and impaired cognitive function. Reviews and meta-analyses of RCTs found an effect of EPA and DHA on improving endothelial function, particularly in patients with CVD risk factors, including hypertension however this was not consistently found in healthy young and middle-aged subjects. This study may explain the greater response to lowering blood pressure in hypertensive patients without treatment, compared with normotensive subjects in this meta-analysis. (Paige et al, 2014) (Wang Q,2012) (Egert, 2011)

The decrease in blood pressure observed in the study conducted by Paige et al, 2014 was not only statistically significant but also clinically significant. In adults, SBP increases by about $0.6 \mathrm{~mm}$ 
$\mathrm{Hg}$ per year, especially in adults aged $\geq 50$ years. In contrast to the research conducted by Wang Q et al and Egert et al, Pagie et al analysis 2014 discovered a statistically significant decrease in SBP of $1.25 \mathrm{~mm} \mathrm{Hg}$ in normotensive individuals which can prevent an increase in SBP with age and can prevent prehypertension status from becoming hypertension. Then it was found a decrease of $4.51 \mathrm{~mm}$ $\mathrm{Hg}$ in the hypertensive population who did not take antihypertensive drugs. These findings confirmed that consumption of EPA and DHA can control hypertension, reduce the progression of hypertension, and prevent complications of hypertension. (Paige et al, 2014) Overall this study did not demonstrate an effect between response and dose to EPA and DHA administration on blood pressure which is similar to findings from a previous Campbell et al meta-analysis. Limited research in the form of comparative data on the content of EPA and DHA in fresh or fortified foods can affect blood pressure reduction. However, it should be underlined that the consumption of fresh fish which is rich in EPA and DHA has some obstacles such as respondents who do not like to eat fish and do not like the fishy smell of fish. (Ruxton, 2011) (Adophus et al,2011)

Research conducted by Paige et al., 2014 confirmed that 5 of 8 previous studies provided recommendations for routine consumption of fatty fish every day, such as sardines, mackerel, and salmon. Evidence from RCTs suggests that a daily supply of $2 \mathrm{~g}$ of EPA and DHA can reduce SBP and DBP, particularly in hypertensive individuals not taking antihypertensive drugs. In addition, lower doses of between 1 and $2 \mathrm{~g}$ per day may also reduce SBP but not DBP. From a clinical and public health perspective, the administration of EPA and DHA can lower blood pressure and ultimately reduce the incidence of associated chronic diseases. (Paige et al, 2014)

The findings of the study conducted by Gian Luca et al., 2016 also bolster the research conducted by Appel et al., 1993 and Morris MC,1993. The findings state that many meta-analyses on the effect of omega 3 on blood pressure have been published. All these meta-analyses confirmed a significant hypotensive effect especially in hypertensive patients who were not taking antihypertensive drugs. Evidence from prospective observational studies suggests that basic omega-3 intake may be associated with future improvement in hypertension. (Yang B et al, 2016) (Campbell et all, 2013) (Miller et all,2014)

Research conducted by Diaz et al, 2021 also proves that in previous studies, systolic blood pressure (SBP) and diastolic blood pressure (DBP) in the type 2 diabetes prevention diet intervention group by adding sardines to the menu $(\mathrm{p}=0.014)$ tended to decrease. In other words, the group that exclusively added sardines to the menu experienced reduced levels of SBP and DBP. In the same vein, Sun $\mathrm{Q}$ et al,2016 stated that taurine supplementation has been shown to reduce BP. Then in a study conducted by Miller et al, 2014 also proved that EPA and DHA supplementation contributed to 
E-ISSN: 2808-5361 http://e-journal.fkmumj.ac.id/
Proceeding The First

Muhammadiyah

Internasional-Public Health

and Medicine Conference

the improvement of blood pressure. Thus, it can be concluded that individuals in the group following a sardine-added diet high in taurine, omega 3, EPA, and DHA relatively indicated a decrease in blood pressure. (Diaz et al, 2021)

\section{CONCLUSIONS AND SUGGESTIONS}

Sardines are marine water fish that are rich in omega 3, EPA, and DHA. In addition, Sardines also contains the amino acid taurine, calcium, iodine, zinc, phosphorus, fluoride, vitamin B12, vitamin D, and antioxidants. Based on several studies, Sardines have a role as anti-inflammatory, antioxidant, increase membrane fluidity increase the number of insulin receptors and insulin action, and have hypotensive and hypoglycemic effects. Thus Sardines are proven to be able to prevent type 2 diabetes mellitus, especially in the senior citizen, prevent hypertension and lower blood pressure. Fresh fish is certainly a better choice than canned fish. Consuming fresh sardines is the best way to get all the nutrients thoroughly. It is highly recommended to consume Sardines at least 200 grams per week. However, if fresh Sardines are difficult to obtain, they can be substituted by consuming fish oil.

The benefits of sardines are clinically proven in lowering blood pressure, preventing hypertension, and type 2 diabetes mellitus in the senior citizen. Based on several studies that have been conducted, nutritional interventions with the addition of fresh sardines of at least 200 grams per week need to be carried out especially for the senior citizen. Then the findings of this study can be considered as a diet for Sardines in the GERMAS program.

However, further research is required to strengthen the previous studies related to the effect of sardines on blood pressure, prevention of hypertension, and type 2 diabetes mellitus in the senior citizen.

\section{THANKYOU-NOTE}

The best gratitude goes to Dr. Dewi Purnamawati, S.KM, M.KM as Advisor for her continuous guidance and direction so that this article can be accomplished properly.

\section{REFERENCES}

1. Kementerian Kesehatan R1. 2018. Laporan Riskesdas 2018. Jakarta: Badan Litbangkes, Kemenkes.

2. Kementerian Kesehatan RI. 2018. Pusat Data dan Informasi Hipertensi. Jakarta: Budijanto, et al

3. Sudoyo WA, Setiyohadi B, Alwi I, Simadibrata M, Setiati S. Buku Ajar Ilmu Penyakit Dalam. $4^{\text {th }}$ Ed. Jakarta: Pusat Penerbitan Departemen IPD FKUI: 2006.

4. Tambayong. Anatomi \& Fisiologi untuk Keperawatan Jakarta; EGC,2001 
5. Padila. Asuhan Keperawatan Penyakit Dalam. Yogyakarta: Nuha Medika, 2013.

6. WHO. Global Report on Diabetes. WHO, 2018.

7. WHO. A global brief on hypertension. WHO, 2013

8. Alfiyah, S. W. Faktor Risiko yang Berhubungan dengan Penyakit Diabetes Melitus pada Pasien Rawat Jalan di Rumah Sakit Umum Pusat Dr. Kariadi Semarang tahun 2010. Universitas Negri Semarang;2011

9. Diaz-Rizzolo DA, Kostov B, Lopez-Siles M, Serra A, Colungo C, González-de- Paz L, et al. Healthy dietary pattern and their corresponding gut microbiota profile are linked to a lower risk of type 2 diabetes, independent of the presence of obesity. Clin. Nutr. 2019.

10. D A Díaz-Rizzolo, A Serra, C Colungo, et al. Type 2 diabetes preventive effects with a 12months sardine-enriched diet in elderly population with prediabetes: An interventional, randomized and controlled trial. Clin. Nutr. 2021.

11. American Diabetes Association. Diagnosing Diabetes and Learning About Prediabetes. ADA. 2015. Diakses dari: http://www.diabetes.org/diabetes- basics/diagnosis/

12. Perkumpulan Endokrinologi Indonesia. Konsensus Pengendalian dan Pencegahan Diabetes Melitus Tipe 2 di Indonesia 2015. PB PERKENI. 2015.

13. Hamman RF, Wing RR, Edelstein SL, Lachin JM, Bray GA, Delahanty L, et al. Effect of weight loss with lifestyle intervention on risk of diabetes. Diabetes Care 2006;29(9):2102e7.

14. Lissner KBL, Odell PM, D'Agostino RB, Stokes J, Kreger BE, Belanger AJ. Variability of body weight and health outcomes in the Framingham population. N Engl J Med1991;324(26):1839e44.

15. Glushakova O, Kosugi T, Roncal C, Mu W, Heinig M, Cirillo P, et al. Fructose induces the inflammatory molecule ICAM-1 in endothelial cells. J Am Soc Nephrol 2008;19(9):1712e20.

16. Kr£ger J, Jacobs S, Jansen EHJM, Fritsche A, Boeing H, Schulze MB. Erythrocyte membrane fatty acid fluidity and risk of type 2 diabetes in the EPIC-Potsdam study. Diabetologia 2015;58(2):282e9.

17. Alhazmi A, Stojanovski E, Garg ML, McEvoy M. Fasting whole blood fatty acid profile and risk of type 2 diabetes in adults: a nested case control study. PloS One

2014;9(5):1e6. 
18. Wang L, Folsom AR, Zheng Z-J, Pankow JS. Plasma fatty acid-composition and 6year incidence of hypertension in middle-aged adults: the atherosclerosis risk in communities (ARIC) study. Am J Epidemiol2012;150(5):492e500.

19. Sertoglu E, Kurt I, Tapan S, Uyanik M, Serdar MA, Kayadibi H, et al. Comparison of plasma and erythrocyte membrane fatty acid compositions in patients with endstage renal disease and type 2 diabetes mellitus. Chem Phys Lipids 2014;178:11e7.

20. Koehler P, Saab S, Berdeaux O, Isaïco R, Grégoire S, Cabaret S, et al. Erythrocyte phospholipid and polyunsaturated fatty acid composition in diabetic retinopathy. PloS One 2014;9(9):e106912.

21. Dickinson HO, Mason JM, Nicolson DJ, Campbell F, Beyer FR, Cook JV, Williams B, Ford GA. Lifestyle interventions to reduce raised blood pressure: a systematic review of randomized controlled trials. J Hypertens 2006;24: 215-233.

22. Campbell F, Dickinson HO, Critchley JA, Ford GA, Bradburn M.A systematic review of fishoil supplements for the prevention and treatment of hypertension. Eur J Prev Cardiol 2013; 20: 107-120.

23. 23. Wang Q, Liang X, Wang L, Lu X, Huang J, Cao J, Li H, Gu D.Effect of omega-3 fatty acids supplementation on endothelial function: a meta-analysis of randomized controlled trials. Atherosclerosis 2012; 221: 536-543.

24. Egert S, Stehle P. Impact of n-3 fatty acids on endothelial function: results from human interventions studies. Curr Opin Clin Nutr Metab Care 2011; 14: 121-131.

25. Ruxton CHS. The benefits of fish consumption. Nutr Bull 2011; 36:6-19.

26. Adophus K, Biac S. Oily fish consumption in young adults: current intakes, knowledge, barriers, and motivations. J Hum Nutr Diet 2011; 24: 375.

27. Paige E. Miller, Mary Van Elswyk, and Dominik D. Alexander Long-Chain Omega-3 Fatty Acids Eicosapentaenoic Acid and Docosahexaenoic Acid and Blood Pressure: A Meta-Analysis of Randomized Controlled Trials. Pubmed 2014 Jul; 27 (7): 885-96.

28. Yang B, Shi M-Q, Li Z-H, dkk. Ikan, rantai panjang n-3 PUFA dan insiden tekanan darah tinggi: meta- analisis studi kohort prospektif. Nutrisi 2016; 8: 58

29. Campbell F, Dickinson HO, Critchley JA, et al. A systematic review of fish-oil supplies for the prevention and treatment of hypertension. Eur J Prev Cardiol 2013; 20: 107-120. [65] Hartweg J, Farmer AJ, Holman RR, et al. Meta-analysis of the effects of n-3 polyunsaturated 
fatty acids on hematological and thrombogenic factors in type 2 diabetes.Diabetologia 2007; 50: 250-258. [66]

30. Miller PE, Van Elswyk M, Alexander DD. Long-chain omega-3 fatty acids eicosapentaenoic acid and docosahexaenoic acid and blood pressure: a meta-analysis of randomized controlled trials. Am J Hypertens 2014; 27: 885-896.

31. JubbinJ Jacob, Soumia Peter et al. A fish a day, keeps the cardiologist away! - A review of the effect of omega-3 fatty acids in the cardiovascular system. Indian Journal of Endocrinology and Metabolism, 17, 3, 2013

32. Byelashov, O., Sinclair, A., \& Kaur, G. (2015). Dietary sources, current intakes, and nutritional role of omega-3 docosapentaenoic acid. Lipid Technology, 27 (4), 79-82. DOI: 10.1002/ lite. 201500013

33. Scientific Opinion on the Tolerable Upper Intake Level of eicosapentaenoic acid (EPA), docosahexaenoic acid (DHA) and docosapentaenoic acid (DPA). (2012). EFSA Journal, 10 (7) doi:10.2903 / j.efsa.2012.2815

34. Calder, P. (2016). Docosahexaenoic Acid. Annals Of Nutrition And Metabolism, 69(1), 821.doi10.1159/000448262

35. Omega-3 Fatty Acids-Health Professional Fact Sheet. Available at https://ods.od.nih.gov/factsheets/O mega3FattyAcids- HealthProfessional/Accessed:2021-05-15 
Volume I Tahun 2021

November 2021
E-ISSN: 2808-5361

http://e-journal.fkmumj.ac.id/
Proceeding The First Muhammadiyah

Internasional-Public Health

and Medicine Conference 